\title{
Characterizing Water Pollution Potential in Life Cycle Impact Assessment Based on Bacterial Growth and Water Quality Models
}

\author{
Shunwen Bai ${ }^{1}$, Xiuheng Wang ${ }^{1, *}$, Xinyue Zhao ${ }^{2}$ and Nanqi Ren ${ }^{1, *}$ \\ 1 State Key Laboratory of Urban Water Resource and Environment, School of Environment, Harbin Institute \\ of Technology, Harbin 150090, China; baishunwen@163.com \\ 2 College of Resources and Environment, Northeast Agricultural University, Harbin 150030, China; \\ zhaoxy@neau.edu.cn \\ * $\quad$ Correspondence: xiuheng@hit.edu.cn (X.W.); rnq@hit.edu.cn (N.R.)
}

Received: 6 October 2018; Accepted: 4 November 2018; Published: 9 November 2018

\begin{abstract}
For the life cycle assessment (LCA) of wastewater management, eutrophication is considered the most relevant factor. However, eutrophication is not the only pathway through which wastewater influences the environment, and merely characterizing eutrophication potential is not sufficient for the LCA framework to reflect the influence of wastewater. This study defines the Bacterial Depletion of Oxygen (BDO) - a new impact category that represents the oxygen depleting potential caused by the growth of microorganisms-and characterization models and characterization factors are developed for the application of BDO. Water quality models (both oneand two-dimensional) are incorporated into the BDO characterization models so that the LCA framework includes some spatially differentiated factors, and can be used to estimate the direct impact of wastewater on receiving environment $\left(I_{B D O}\right.$ value). Based on three case studies, this study demonstrates how the BDO category can be applied for the evaluation of wastewater management. Results show that increases in the downstream distance and self-purification coefficients reduce the $I_{B D O}$ value, whereas the increase in water velocity raises the $I_{B D O}$ value. Future integration of the BDO category with water quality models must link the dilution effect of water bodies, the environmental carrying capacity of receiving water, and the distribution of water pollutants in eutrophication and bacterial oxygen depletion.
\end{abstract}

Keywords: life cycle assessment; methodology; oxygen-depleting potential; wastewater treatment

\section{Introduction}

Increasingly sophisticated discharge requirements and the requirement to avoid shifting the burden from one environmental impact to another have necessitated the application of scientific tools to the decision-making process concerning wastewater management. Life cycle assessment (LCA) has been widely used for the environmental evaluation of wastewater management [1-10], and eutrophication is considered the most relevant impact category [7]. Accordingly, most of the methodological LCA progress in regards to wastewater management has focused on the development of a eutrophication impact category [11-15]. These methods enable the examination of the potential impacts of eutrophication in freshwater and marine ecosystems associated with the development of fate and transport models [16].

Eutrophication is not the only type of water pollution. The depletion of oxygen due to the growth of microorganisms is another important pathway through which wastewater influences the environment, especially for wastewater that contains a large amount of organics pollutants [17]. 
Specifically, when wastewater flows into water bodies without treatment, organic pollutants such as carbohydrates, protein, and organic acid can encourage the growth of aerobic bacteria, consuming vast amounts of dissolved oxygen (DO). If the oxygen supply from air and photosynthesis is lower than the oxygen consumption, the DO concentration decreases. Once the concentration approaches zero, the growth of anaerobic bacteria is stimulated and the water conditions deteriorate, killing aquatic species and causing serious water pollution associated with the release of unpleasant smell and depreciated value. Deterioration of water quality due to organic enrichment is a major environmental issue in industrialization and urbanization. In China, water pollution caused by microorganism growth has been found in many contaminated rivers $[18,19]$, and reducing this kind of pollution has become the objective of many environmental policies introduced by the Chinese government [20,21].

In general, LCA results have a high level of abstraction without referring to any specific situations [22]. Generalizable LCA results are justifiable for environmental impacts with large-scale characteristics such as global warming [23]. For emissions that directly impact the regional environment, however, it is crucial for the LCA framework to incorporate spatially differentiated factors to obtain more representative results. This is especially important when conducting LCA for wastewater-related issues because the emissions of water pollutants directly affect regional water bodies [24,25]. In previous LCA studies, some regional characterization factors or models for eutrophication have been developed, including spatially explicit factors at the lake- or stream-level [11-13], spatially differentiated factors for different emission sources, and a fate model for phosphorus emissions on the continent and country scales [14,15]. However, most studies did not consider the transport and transformation of water pollutants, including organic matter, nitrogen, and phosphorus, in the receiving environment. When released into water bodies, water pollutants move and undergo processes that often involve simultaneous biological, chemical, and physical reactions [17]. Due to this variety of mechanisms, the pollutant concentration varies in different parts of water bodies, with different potential impacts. Such situations have rarely been included in current calculation LCA frameworks. This highlights the need to incorporate the fate of water pollutants in LCA frameworks for obtaining estimation results that represent the direct impact of water pollutants on different parts of water bodies. Water quality models (WQM) are effective tools for simulating and predicting the fate and behavior of pollutants in water environments [26]. WQM include some geological, chemical, or physical factors related to the water environment, and can be used to identify the levels in different parts of a water environment.

The goal of this study wastwo2-fold. First, a new impact category is defined for LCA system, the Bacterial Depletion of Oxygen (BDO), to characterize the oxygen depleting potential that is encouraged by the growth of microorganisms due to the release of water pollutants. Following the general framework for characterization, characterization models for the BDO category are developed. Second, WQM are incorporated into the characterization models with a BDO category. The LCA system includes the transport and transformation of water pollutants in the receiving environment, and can be used to estimate the direct impact of organic pollutants on the different parts of the receiving environment.

\section{Methods and Materials}

\subsection{Bacterial Depletion of Oxygen}

This study defines an independent impact category named the Bacterial Depletion of Oxygen (BDO), which is in parallel with other impact categories in LCA, such as eutrophication, global warming, or acidification. The BDO category is defined to represent the oxygen depleting potential caused by the growth of microorganisms due to the release of water pollutants. Based on the general characterization LCA framework [27], the characterization model for BDO category is described as:

$$
I_{B D O}(S)=\sum_{p} B D O_{p} \times m_{p}
$$


where $S$ is the area affected by the substance $p, p$ refers to water pollutants that can stimulate the growth of bacteria, $I_{B D O}(S)$ refers to the characterization results of the BDO impact category, $m_{p}$ is the emitted amount of substance $p$, and $B D O_{p}$ is the characterization factors, representing the potential contribution of substance $p$ to bacterial growth.

Characterization factors $\left(B D O_{p}\right)$ are calculated by aggregating the potential contribution of water pollutants to the growth of microorganisms. In this study, organic matter (measured as the chemical oxygen demand, or COD), nitrogen (measured as the total nitrogen, $\mathrm{TN}$ ) and phosphorus (measured as the total phosphorus, TP) are considered the major water pollutants (substance $p$ ) involved in the depletion of oxygen in receiving water bodies. The formula describing the characterization factors is:

$$
B D O_{p}=\frac{\frac{v_{p}}{M_{p}}}{\frac{v_{r e f}}{M_{r e f}}}
$$

where $v_{p}$ and $v_{r e f}$ represent the potential contribution to the bacterial growth by one mole of the substance $p$ and the reference substance, respectively; and $M_{p}$ and $M_{r e f}$ refer to the molar mass of the substance $p$ and the reference substance, respectively. There are three types of reference substance $p$ : oxygen $\left(\mathrm{O}_{2}\right)$, nitrate $\left(\mathrm{NO}_{3}{ }^{-}\right)$, and phosphate $\left(\mathrm{PO}_{4}{ }^{3-}\right)$. When characterizing the potential growth of bacteria in a LCA, choosing $\mathrm{O}_{2}$ can provide an intuitive measure of oxygen depletion ( $\mathrm{kg} \mathrm{O}_{2}$ eq.), whereas selecting $\mathrm{NO}_{3}{ }^{-}\left(\mathrm{kg} \mathrm{NO}_{3}{ }^{-}\right.$eq.) or phosphate $\mathrm{PO}_{4}{ }^{3-}$ ( $\mathrm{kg} \mathrm{PO}_{4}{ }^{3-}$ eq.) can contribute to a direct comparison between the newly defined BDO category and the currently available eutrophication category [27]. Of note, the identification of substance references would minimally influence the characterization of environmental impact in LCA. Therefore, the potential contribution of reference substance $\left(v_{r e f}\right)$ is usually assigned a value of 1 [28].

The determination of $v_{p}\left(v_{T N}, v_{T P}\right.$, and $\left.v_{C O D}\right)$ is based on the identification of the characterization state. Given the scientific background of the eutrophication category, the average chemical composition of aquatic organisms $\left(\mathrm{C}_{106} \mathrm{H}_{263} \mathrm{O}_{110} \mathrm{~N}_{16} \mathrm{P}\right)$ is assumed to be representative of average biomass [27]. This study determines the growth of bacteria with the characterization state of the BDO category, and $v_{p}$ is calculated on the basis of the stoichiometry and the chemical composition of the bacterial biomass $\left(\mathrm{C}_{n} \mathrm{H}_{a} \mathrm{O}_{b} \mathrm{~N}_{c}\right)$ [29]:

$$
\mathrm{C}_{n} \mathrm{H}_{a} \mathrm{O}_{b} \mathrm{~N}_{c}+\left(\frac{2 n+0.5 a-1.5 c-b}{2}\right) \mathrm{O}_{2} \rightarrow n \mathrm{CO}_{2}+c \mathrm{NH}_{3}+\left(\frac{a-3 c}{2}\right) \mathrm{H}_{2} \mathrm{O}
$$

where one mole of the bacterial biomass $\left(C_{n} H_{a} O_{b} N_{c}\right)$ requires $c$ moles of $N$ and $(2 n+0.5 a-1.5 c-$ b) $/ 2$ moles of chemical oxygen demand (COD) and $v_{p}$ is calculated as:

$$
\begin{gathered}
v_{T N}=\frac{1}{c} \\
v_{C O D}=\frac{1}{\left(\frac{2 n+0.5 a-1.5 c-b}{2}\right)} \\
v_{T P}=0
\end{gathered}
$$

\subsection{Incorporation of Water Quality Models into the LCA Framework}

To include the fate of water pollutants in the LCA framework, this study incorporates water quality models (WQM) into the characterization model of the BDO category. Two kinds of WQM were selected in this study: the one-dimensional (1D) model and the two-dimensional (2D) model. In this study, the BDO characterization model coupled with 1D is called the one-dimensional coupling characterization model (1DCCM), and the BDO characterization model coupled with 2D is called the two-dimensional coupling characterization model (2DCCM). 


\subsubsection{Descriptions of $1 \mathrm{D}$ and 2D}

The development of 1D is based primarily on the Streeter-Phelps oxygen-sag equation and the steady-state assumption that constant parameters are required, such as the flow rate of waste [30]. 1D is often used for small-sized rivers [31]. In the 1D model, the concentration of water pollutants is assumed to vary along the longitudinal orientation, while all waste constituents are assumed to be completely mixed vertically and laterally within any cross section [32]. The equations describing 1D are as follows:

$$
\begin{gathered}
\frac{\partial c}{\partial t}+u \frac{\partial c}{\partial x}=E \frac{\partial^{2} c}{\partial x^{2}}-k c \\
\frac{\partial z}{\partial t}+\frac{1}{B} \frac{\partial Q}{\partial x}=q_{t} \\
\frac{\partial Q}{\partial t}+\frac{\partial}{\partial x}\left(\frac{Q^{2}}{A}\right)+g A\left(\frac{\partial z}{\partial x}+\frac{Q|Q|}{A}\right)=0
\end{gathered}
$$

where Equation (4) is the differential equation for 1D, Equation (5) is the continuity equation of flow, Equation (6) is the momentum equation for the longitudinal orientation, $c$ is the pollutant concentration, $u$ is the velocity of the receiving water, $E$ is the longitudinal dispersion coefficient, $t$ is the time required for the pollutant to move over one cross-section, $x$ is the longitudinal distance that pollutant travels through the cross-section, $k$ is the self-purification coefficient of the pollutant, $z$ is the water level, $Q$ is the rate of flow, $B$ is the width of the receiving water, $A$ is the cross-sectional area, and $g$ is the gravitational acceleration, $q_{t}$ is the flow rate arising from the side-river.

Based on Equations (4)-(6), the concentration of pollutants along the longitudinal orientation can be described as:

$$
C(x)=\frac{m}{A u} \exp \left(-\frac{k x}{u}\right)
$$

where $C(x)$ is the pollutant concentration at the cross-section, which is $x$ meters away from the emission point, and $m$ is the emitted amount of the pollutant.

The development of $2 \mathrm{D}$ is based upon the finite-difference solution of the vertically averaged equations of fluid motion [33,34]. 2D describes time-varying lateral and longitudinal distributions of water pollutants in a water body, and is often used for large water bodies including large-sized rivers, reservoirs, lakes, and estuaries [35]. The use of 2D depends on the assumption that water quality varies along the longitudinal and lateral axes of a water-body, and all waste constituents are assumed to be completely mixed vertically [34]. The equations describing 2D are as follows:

$$
\begin{gathered}
\frac{\partial c}{\partial t}+u_{x} \frac{\partial c}{\partial x}+u_{y} \frac{\partial c}{\partial y}=M_{x} \frac{\partial^{2} c}{\partial x^{2}}+M_{y} \frac{\partial^{2} c}{\partial y^{2}}-k c \\
\frac{\partial \rho z}{\partial t}+\frac{\partial \rho H u_{x}}{\partial x}+\frac{\partial \rho H u_{y}}{\partial y}=0 \\
\frac{\partial \rho H u_{x}}{\partial t}+\frac{\partial}{\partial x}\left(\rho H u_{x} u_{x}\right)+\frac{\partial}{\partial y}\left(\rho H u_{y} u_{x}\right)=-\rho g H \frac{\partial z}{\partial x}+\frac{\partial}{\partial x}\left(H \gamma_{e f f} \frac{\partial u_{x}}{\partial x}\right)+\frac{\partial}{\partial y}\left(H \gamma_{e f f} \frac{\partial u_{x}}{\partial y}\right)-\tau_{h x} \\
\frac{\partial \rho H u_{y}}{\partial t}+\frac{\partial}{\partial x}\left(\rho H u_{x} u_{y}\right)+\frac{\partial}{\partial y}\left(\rho H u_{y} u_{y}\right)=-\rho g H \frac{\partial z}{\partial y}+\frac{\partial}{\partial x}\left(H \gamma_{e f f} \frac{\partial u_{y}}{\partial x}\right)+\frac{\partial}{\partial y}\left(H \gamma_{e f f} \frac{\partial u_{y}}{\partial y}\right)-\tau_{h y}
\end{gathered}
$$

where Equation (8) is the differential equation of 2D; Equation (9) is the continuity equation of flow; Equations (10) and (11) are the momentum equation for the longitudinal orientation and lateral orientation, respectively; $c$ is the pollutant concentration; $k$ is the self-purification coefficient of the pollutant; $t$ is the time required for the pollutant to transfer; $u_{x}$ and $u_{y}$ are water velocities along the longitudinal and lateral orientation, respectively; $M_{x}$ and $M_{y}$ are longitudinal and horizontal dispersion coefficients, respectively; $x$ is the longitudinal distance from emission point to downstream impact point; $y$ is the lateral distance from emission point to downstream impact point; $H$ is the 
average depth of receiving water; $g$ is the gravitational acceleration; $\rho$ is the water density; $z$ is the water level; $\tau_{h x}$ is the momentum coefficient along $\mathrm{x}$ orientation and $\tau_{h y}$ is the momentum coefficient along y orientation; $\gamma_{e f f}$ is the coefficient of virtual viscosity.

Based on Equations (8)-(11), the concentration of pollutants at the downstream impact point $(x, y)$ can be described as:

$$
C(x, y)=C_{p} \times Q_{p} \times \exp \left(-k_{86400 u_{x}}\right) \times \frac{1}{H \times \sqrt{\pi M_{y} x u_{x}}} \times\left[\exp \left(-\frac{u_{x} y^{2}}{4 M_{y} x}\right)+\exp \left(-\frac{u_{x}(2 B-y)^{2}}{4 M_{y} x}\right)\right]
$$

where $C(x, y)$ is the pollutant concentration at the downstream impact point $(x, y), Q_{p}$ is the flow rate of the emission point, and $C_{p}$ is the pollutants concentration at the emission point.

\subsubsection{Development of $1 \mathrm{DCCM}$ and $2 \mathrm{DCCM}$}

This study defines a time-varying mass parameter for the BDO characterization model, and Equation (1) can be described as follows:

$$
\begin{gathered}
I_{B D O}(x)=\sum_{p}\left[B D O_{p} \times m_{p, t}(x)\right] \\
I_{B D O}(x, y)=\sum_{p}\left[B D O_{p} \times m_{p, t}(x, y)\right]
\end{gathered}
$$

where $m_{p, t}(x)$ and $m_{p, t}(x, y)$ are the masses of the pollutant that travel through a cross-section $(x)$ or an impact point $(x, y)$ at a given time $t$, respectively; $m_{p, t}(x)$ is determined by the flow rate of receiving water and the $C(x)$ of 1D; and $m_{p, t}(x, y)$ is determined by the flow rate of receiving water and the $C(x, y)$ of $2 \mathrm{D}$.

The 1DCCM was developed by combing Equations (7) and (13), and can be described as follows:

$$
I_{B D O}(x)=\sum_{p}\left[B D O_{p} \times m_{p, t}(x) \times \exp \left(-k_{p} \frac{x}{u}\right)\right]
$$

where $I_{B D O}(x)$ is the characterization result of the BDO category, representing the oxygen depleting potential of the emitted water pollutants at the cross-section that is $x$ meters away from the emission point; COD and TN are considered the major water pollutants (substance $p$ ); and $t$ is the time required for water pollutants to reach the cross-section, determined by $x$ and $u$.

The 2DCCM was developed by combing Equations (12) and (14), and can be described as follows:

$$
\begin{aligned}
I_{B D O}(x, y)=\left\{\sum_{p}\right. & {\left.\left[B D O_{p} \times m_{p, t}(x, y) \times \exp \left(-k_{p} \frac{x}{u}\right)\right]\right\} \times\left[\frac{1}{\left(H \sqrt{\left.\pi M_{y} x u_{x}\right)}\right.}\right] } \\
\times & {\left[\exp \left(-\frac{u_{x} y^{2}}{4 M_{y} x}\right)+\exp \left(-\frac{u_{x}(2 B-y)^{2}}{4 M_{y} x}\right)\right] }
\end{aligned}
$$

where $I_{B D O}(x, y)$ is the characterization result of the BDO category, which represents the oxygen depleting potential of the emitted water pollutants at the impact point $(x, y)$.

\subsection{Identification of Atrazine and Its Metabolites}

We first demonstrates how to calculate the characterization factors for the BDO category. The growth of bacteria (mixed cultures and pure cultures) are determined as the characterization state. The potential contribution by one mole of substance $p\left(v_{p}\right)$ to the bacterial growth w calculated by incorporating the bacterial empirical formula into Equation (3). The selected bacterial empirical formula included $\mathrm{C}_{5} \mathrm{H}_{7} \mathrm{O}_{2} \mathrm{~N}, \mathrm{C}_{7} \mathrm{H}_{12} \mathrm{O}_{4} \mathrm{~N}, \mathrm{C}_{9} \mathrm{H}_{15} \mathrm{O}_{5} \mathrm{~N}, \mathrm{C}_{9} \mathrm{H}_{16} \mathrm{O}_{5} \mathrm{~N}, \mathrm{C}_{4.9} \mathrm{H}_{9.4} \mathrm{O}_{2.9} \mathrm{~N}, \mathrm{C}_{4.7} \mathrm{H}_{7.7} \mathrm{O}_{2.1} \mathrm{~N}$, $\mathrm{C}_{4.9} \mathrm{H}_{9} \mathrm{O}_{3} \mathrm{~N}, \mathrm{C}_{5} \mathrm{H}_{8.8} \mathrm{O}_{3.2} \mathrm{~N}, \mathrm{C}_{4.1} \mathrm{H}_{6.8} \mathrm{O}_{2.2} \mathrm{~N}, \mathrm{C}_{5.1} \mathrm{H}_{8.5} \mathrm{O}_{2.5} \mathrm{~N}$ and $\mathrm{C}_{5.3} \mathrm{H}_{9.2} \mathrm{O}_{2.5} \mathrm{~N}$ (for mixed culture), as well as the $\mathrm{C}_{5} \mathrm{H}_{8} \mathrm{O}_{2} \mathrm{~N}, \mathrm{C}_{5} \mathrm{H}_{8.33} \mathrm{O}_{0.81} \mathrm{~N}, \mathrm{C}_{4} \mathrm{H}_{8} \mathrm{O}_{2} \mathrm{~N}, \mathrm{C}_{4.17} \mathrm{H}_{7.42} \mathrm{O}_{1.38} \mathrm{~N}, \mathrm{C}_{4.54} \mathrm{H}_{7.91} \mathrm{O}_{1.95} \mathrm{~N}, \mathrm{C}_{4.17} \mathrm{H}_{7.21} \mathrm{O}_{1.79} \mathrm{~N}$, $\mathrm{C}_{4.16} \mathrm{H}_{8} \mathrm{O}_{1.25} \mathrm{~N}$, and $\mathrm{C}_{3.85} \mathrm{H}_{6.69} \mathrm{O}_{1.78} \mathrm{~N}$ (for pure cultures). All empirical equations were determined 
from the technical book. The COD and TN were identified for the substance $p$; therefore, he $v_{C O D}$ and $v_{T N}$ could be determined. TP was excluded because its minimal contribution identified by Equation (3). The characterization factors of the BDO category were calculated by introducing $v_{C O D}$ and $v_{T N}$ into Equation (2).

We then investigated the application of 1DCCM and 2DCCM. 1DCCM was applied to a small-sized river, the Ashihe river located in China. One river reach of the Ashihe river was selected in this study: the reach from Xiquanyan to Maan mountain. The impact of a single parameter on the characterization results of $\mathrm{BDO}, I_{B D O}(x)$, was explored, and the parameters included the downstream cross-section that is $x$ meters away from the emission point, the self-purification coefficient of COD $\left(k_{C O D}\right)$, and the water velocity $(u)$. We explored the combined impact of these parameters on $I_{B D O}(x)$. 2DCCM was applied to a large-sized river, the Songhua river, located in China. The Harbin mainstay of the Songhua river was selected, which is $16.25 \mathrm{~km}$ long, $450 \mathrm{~m}$ wide, and $2.3 \mathrm{~m}$ deep. We explored the change in $I_{B D O}(x)$ along the longitudinal orientation at different lateral sections. Six lateral sections of the Harbin mainstay were selected: $y=0 \mathrm{~m}, 50 \mathrm{~m}, 100 \mathrm{~m}, 150 \mathrm{~m}, 200 \mathrm{~m}$, and $250 \mathrm{~m}$. Both the rivers were assumed to be affected by an emission point. The flow rate of wastewater was $10,000 \mathrm{~m}^{3} / \mathrm{day}$, and the COD of raw wastewater was $259.2 \mathrm{mg} / \mathrm{L}$ and TN was $28.7 \mathrm{mg} / \mathrm{L}$.

We finally conducted a complete LCA analysis using the CML method (the most widely used LCA method developed by Leiden University) on a full-scale wastewater treatment plant (WWTP) using the BDO category and 1DCCM. The WWTP is located near the bank of the Ashihe river, and the major treatment technology is cyclic activated sludge technique, operated at capacity of $10,000 \mathrm{~m}^{3} / \mathrm{day}$. The components of raw wastewater entering the WWTP included a COD of $259.2 \mathrm{mg} / \mathrm{L}, \mathrm{TN}$ of $28.7 \mathrm{mg} / \mathrm{L}$, TP of $3.4 \mathrm{mg} / \mathrm{L}$, and suspended solids of $187.4 \mathrm{mg} / \mathrm{L}$. The goal of the LCA analysis was to investigate the environmental impact of different wastewater treatment levels. Three scenarios were defined for the LCA analysis based on the three wastewater treatment levels: scenario 1 (tertiary treatment), scenario 2 (intermediate treatment), and scenario 3 (basic treatment). The 10,000 $\mathrm{m}^{3}$ of wastewater emitted per day was chosen as the functional unit. The operational stage of the WWTP was evaluated, and the system boundaries included sewage treatment, electricity production, chemical manufacturing and transportation, and waste-activated sludge processing. The BDO category ( $\mathrm{kg} \mathrm{NO}_{3}{ }^{-}$eq.) was used in parallel with the other impact categories of the CML method, and these impact categories included acidification ( $\mathrm{A}, \mathrm{kg} \mathrm{SO}_{2}{ }^{-}$eq.), freshwater aquatic ecotoxicity (FAET, $\mathrm{kg}$ 1,4-DCB eq.), human toxicity (HT, kg 1,4-DCB eq.), ozone depletion (OD, kg CFC-11 eq.), photochemical oxidation (PO, $\mathrm{kg}$ ethylene eq.), global warming ( $\mathrm{GW}, \mathrm{kg} \mathrm{CO}_{2}$ eq.), abiotic depletion of fossil fuels (ADF, MJ), and abiotic depletion of elements (ADE, kg antimony eq.). We determined five cross-sections for the LCA analysis: section 1 (100 m away from the emission point), section 2 (20,000 $\mathrm{m}$ away), section 3 (40,000 $\mathrm{m}$ away), section 4 (60,000 $\mathrm{m}$ away), and section 5 (80,000 $\mathrm{m}$ away).

\section{Results}

\subsection{Characterization Factors of BDO}

The characterization factors for the BDO category were calculated (Table 1). The values of 1 , 4.4286, and 6.7857 for $B D O_{T N}$ (characterization factor of $\mathrm{TN}$ ) were obtained for both mixed cultures and pure cultures when selecting $\mathrm{O}_{2}, \mathrm{NO}_{3}{ }^{-}$, and $\mathrm{PO}_{4}{ }^{3-}$ as the reference substance, respectively. All the selected bacterial empirical equations produced the same number of nitrogen atoms and the same potential contribution of substance $N$ to the bacterial growth $\left(v_{T N}=1\right)$. The values of $B D O_{C O D}$ (characterization factor of COD) depended on the identification of the bacterial empirical formula, varying with the different environmental conditions and reference substances. For the following study, the selection of the environmental conditions or the reference substances had little influence. Accordingly, the averaged characterization factors (0.3759 of $B D O_{C O D}$ and 4.4286 of $\left.B D O_{T N}\right)$ were used with the reference substance being $\mathrm{NO}_{3}{ }^{-}$. 
Table 1. Characterization factors for COD and TN with respect to the impact category of BDO based on different environmental conditions and reference substances $\left(\mathrm{O}_{2}, \mathrm{NO}_{3}{ }^{-}\right.$, and $\left.\mathrm{PO}_{4}{ }^{3-}\right)$.

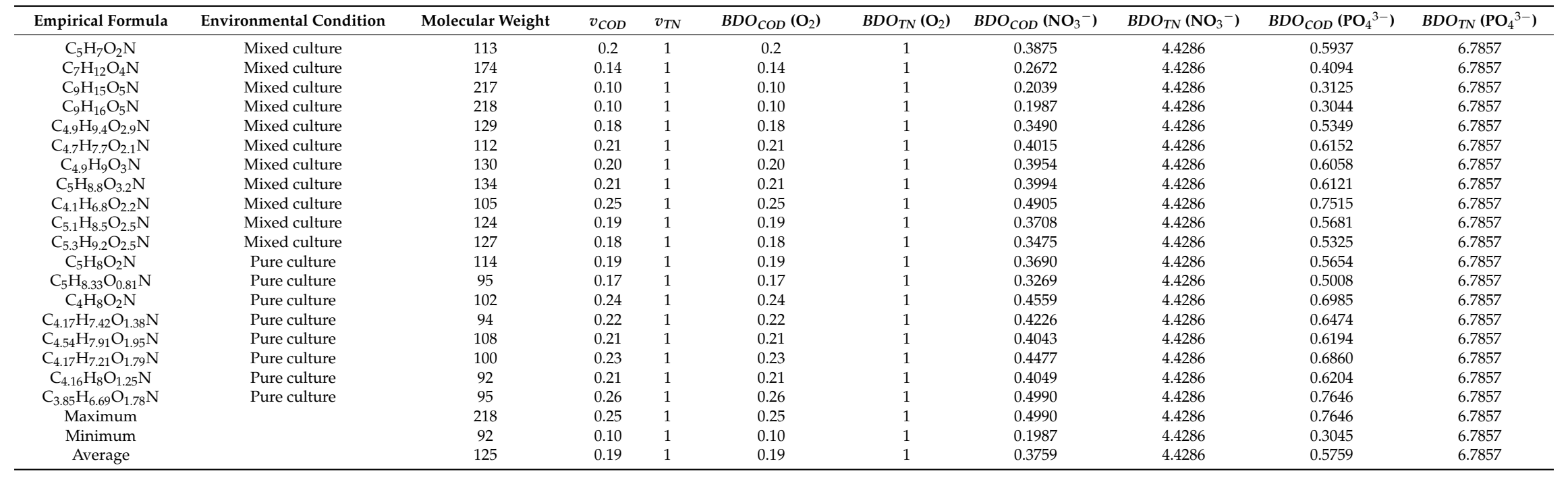




\subsection{Application of $1 D C C M$ and $2 D C C M$}

Based on 1DCCM, we explored the impact of single parameters on the characterization results of the BDO category. The selected parameters included the downstream cross-section distance $(x)$, self-purification coefficient of COD $\left(k_{C O D}\right)$, and water velocity $(u)$.

As shown in Figure 1, the characterization results $\left(I_{B D O}\right)$ showed decreasing tendencies with increasing $k_{C O D}$ and $x$, whereas an increasing tendency with increasing $u$ was observed. Temperature was a main contributor to the change in the self-purifying coefficient: the higher the temperature, the higher the $k_{C O D}$. In general, the metabolic activity of microorganisms in the receiving water is enhanced by the increase in water temperature. This indicated that with the increase in water temperature, the self-purifying capacity of the receiving water would be stronger (leading to the increase in $k_{C O D}$ ), and more water pollutants could be degraded before being transported to downstream cross-sections (leading to the decrease in $I_{B D O}$ ).
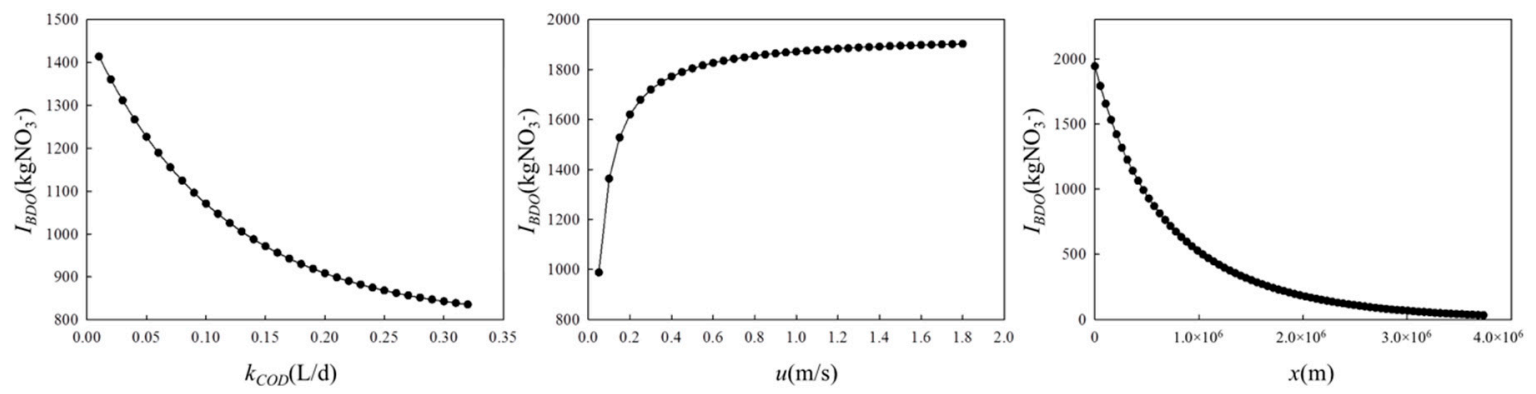

Figure 1. Characterization results for BDO impact category in response to the change of single factor including $k_{\mathrm{COD}}, x$, and $u(1 \mathrm{DCCM})$.

With the increase in water velocity $(u)$, a shorter period would be required or water pollutants to be self-purified by the receiving water; therefore, more water pollutants could be left to impact the downstream cross-section (leading to the increase in $\left.I_{B D O}\right)$. Accordingly, with the increase in downstream cross-section distance $(x)$, the receiving water would have more time to self-purify, leading to a lower environmental impact on the downstream cross-section (a decrease in $I_{B D O}$ ).

In reality, factors such as self-purifying coefficients $(k)$ and water velocity $(u)$ vary with the change in environmental conditions, and these factors would impact the receiving water's self-purifying capacity synthetically but not separately. In our case (the Harbin mainstay of the Songhua river), all three parameters $\left(u, k_{C O D}\right.$, and $\left.k_{T N}\right)$ changed during various periods. For example, from March to April, the values of these parameters increased. As described above, the increased water velocity $(u)$ had a tendency to increase $I_{B D O}$, whereas the increased self-purifying coefficients $\left(k_{C O D}\right.$ and $\left.k_{T N}\right)$ had a tendency to decrease $I_{B D O}$.

Based on the 1DCCM, it was possible to investigate the combined impact of the three increased parameters on the $I_{B D O}$. As shown in Figure 2, the value of $I_{B D O}$ in April $\left(1882 \mathrm{kgNO}_{3}{ }^{-}\right)$was higher than the value in March $\left(1626 \mathrm{kgNO}_{3}{ }^{-}\right)$, indicating that the decreasing tendency driven by $k_{\mathrm{COD}}$ and $k_{T N}$ was overwhelmed by the increasing tendency driven by $u$. 


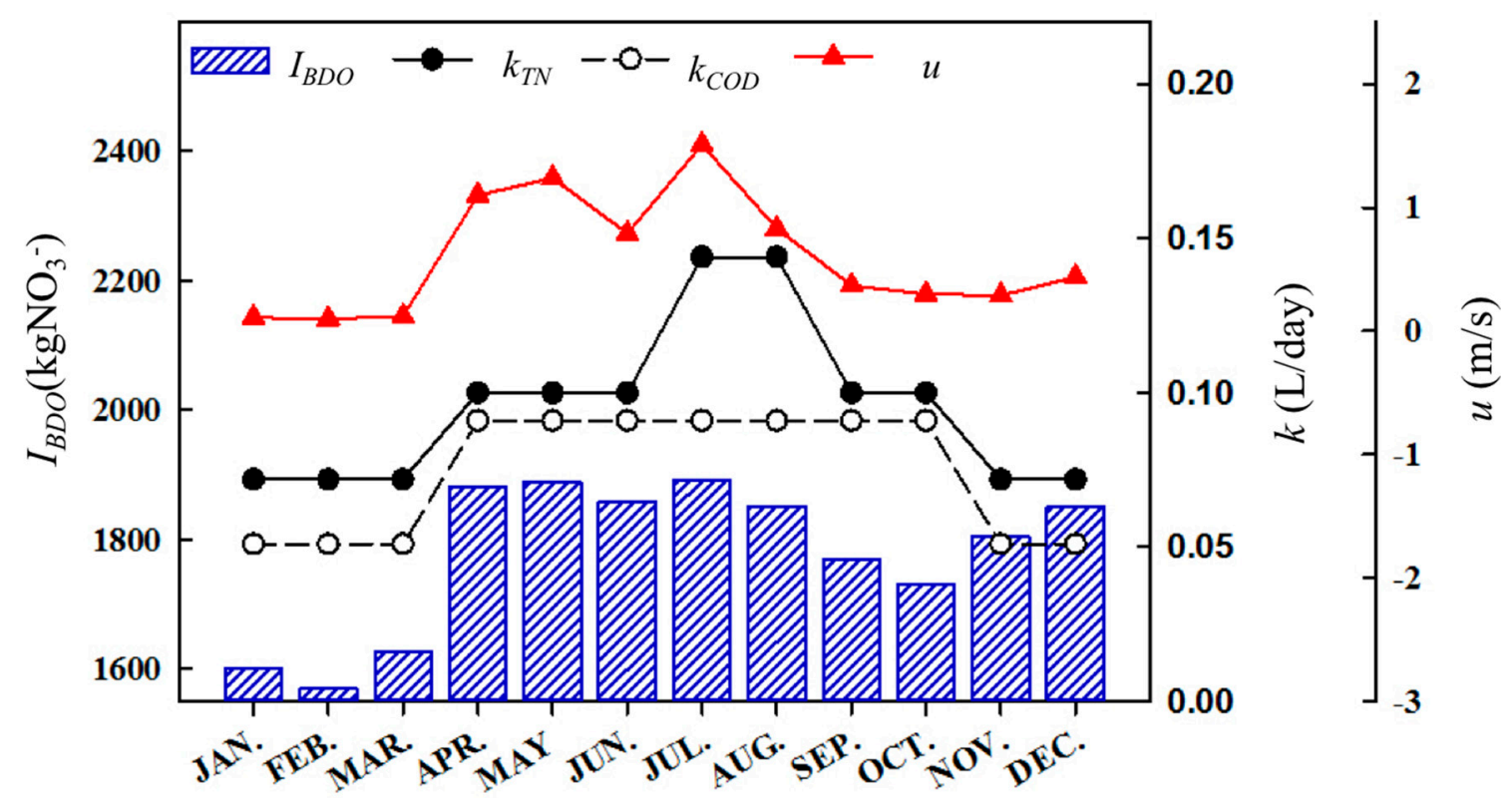

Figure 2. Characterization results for BDO impact category in response to the combined change in water velocity $(u)$ and self-purification coefficients $\left(k_{C O D}, k_{T N}\right)$ using $1 \mathrm{DCCM}$ for the Ashihe river for different months.

\subsection{Results of $I_{B D O}$ Obtained from $2 D C C M$}

With 2DCCM, more detailed information about the migration and transportation of water pollutants in the receiving water could be converted into the LCA characterization results. Figure 3 describes the longitudinal ( $x$-axis) gradients of $I_{B D O}$ at different horizontal ( $y$-axis) river sections. Results of $I_{B D O}$ at the horizontal section of $y=0 \mathrm{~m}$ showed a reducing tendency ranging from $1956 \mathrm{kgNO}_{3}{ }^{-}(x=0 \mathrm{~m}, y=0 \mathrm{~m})$ to $723 \mathrm{kgNO}_{3}{ }^{-}(x=0 \mathrm{~m}, y=7000 \mathrm{~m})$ and stabilized at $558 \pm$ $69 \mathrm{kgNO}_{3}{ }^{-}$for the rest of the longitudinal distances. However, at the horizontal sections of $y=50 \mathrm{~m}$ and $y=100 \mathrm{~m}$, the characterization results showed increasing tendencies, with $I_{B D O}$ stabilizing at $453 \pm 42 \mathrm{kgNO}_{3}{ }^{-}$and $231 \pm 9 \mathrm{kgNO}_{3}{ }^{-}$, respectively. For the other horizontal sections of $y=150 \mathrm{~m}$, $y=200 \mathrm{~m}$, and $y=250 \mathrm{~m}$, characterization results were almost quantitatively negligible. One possible reason for this finding might be that few water pollutants migrated to these sections in this study case. 


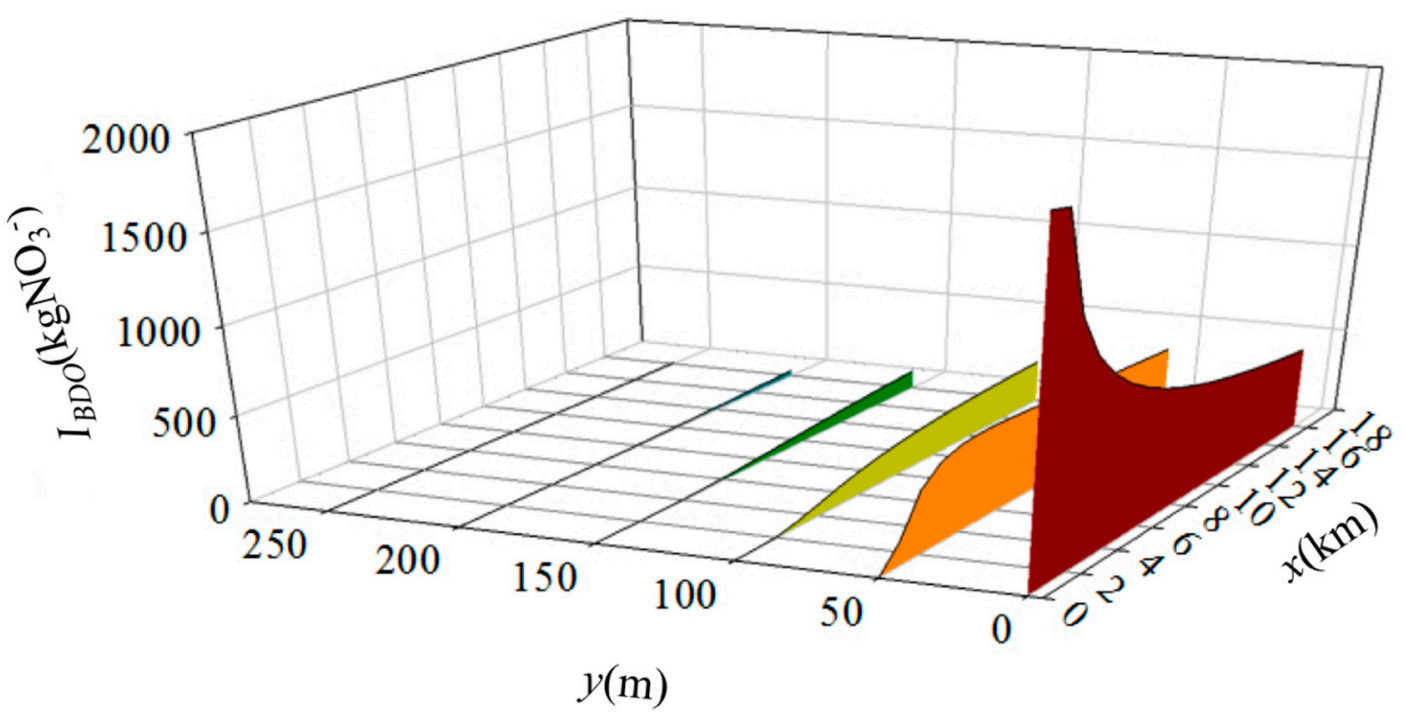

Figure 3. Longitudinal gradients of characterization results for the BDO impact category at different horizontal sections using 2DCCM for the Songhua river, China. Six horizontal sections were defined: $y=0 \mathrm{~m}, 50 \mathrm{~m}, 100 \mathrm{~m}, 150 \mathrm{~m}, 200 \mathrm{~m}$, and $y=250 \mathrm{~m}$.

\subsection{Comparison of Total Environmental Impact and $I_{B D O}$ for Different Scenarios}

From scenario 3 to scenario 2, reduction of $I_{B D O}$ and decrease in total impact were evident for all downstream sections (Figure 4). This means that upgrading the WWTP from basic treatment to intermediate treatment would be beneficial for both the receiving water and the environment overall.

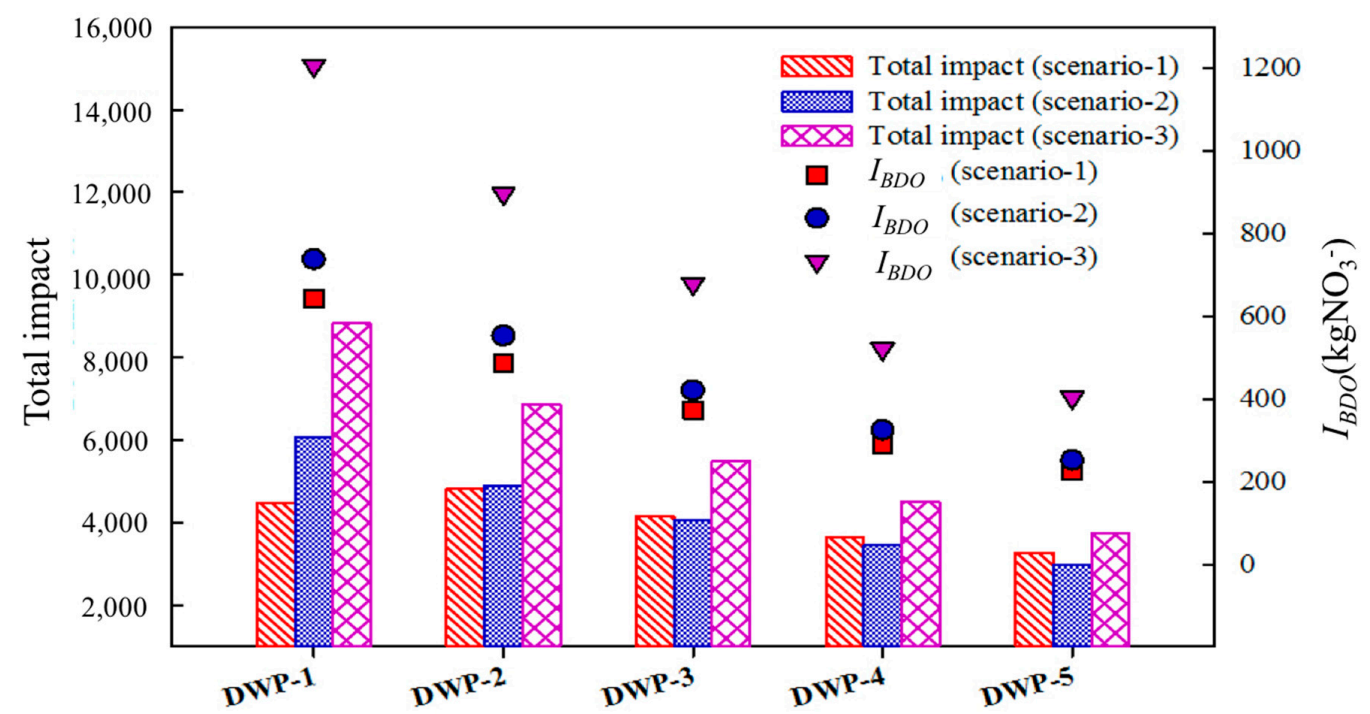

Figure 4. Comparison of total environmental impact and BDO characterization results among different scenarios at different longitudinal parts of receiving water using 1DCCM in a full LCA analysis relevant to WWTP. Five downstream water body areas are defined here: DWP-1 (distance of $100 \mathrm{~m}$ from downstream water body part to emission point), DWP-2 (20,000 m), DWP-3 (40,000 m), DWP-4 $(60,000 \mathrm{~m})$, and DWP-5 (80,000 m).

With respect to the escalation from intermediate treatment to tertiary treatment, scenario 1 showed lower $I_{B D O}$ results than scenario 2 at all downstream locations, but the magnitude of reduction decreased gradually from DWP-1 $\left(95.16 \mathrm{kgNO}_{3}{ }^{-}\right)$to DWP-5 $\left(26.56 \mathrm{kgNO}_{3}{ }^{-}\right)$. We compared total impact between scenario 1 and scenario 2, with scenario 1 being lower than scenario 2 at DWP-1 but higher at DWP-5. These results indicated that when examining the environmental implications of upgrading to tertiary treatment from intermediate treatment, the upgrade appeared beneficial if the 
evaluated downstream location was near the emission point, whereas the upgrade was probably not favorable if the evaluated downstream was far from the emission point.

\subsection{Contribution of Impact Categories on Total Environmental Impact}

Using 1DCCM provided further insight into how the contribution of different impact categories for one scenario would change with different environmental conditions. Taking scenario 1 as an example (Table 2), BDO accounted for $57.37 \%$ of the total impact at DWP-1 $(100 \mathrm{~m})$ but the percentage decreased to $41.49 \%$ at DWP-5 $(80,000 \mathrm{~m})$. For the other impact categories, ADF of $6.87 \%$, GW of $8.38 \%$, FAET of $13.74 \%$, and A of $7.85 \%$ were obtained at DWP-1, but ADF of $9.43 \%$, GW of $11.51 \%$, FAET of $18.86 \%$, and $\mathrm{A}$ of $10.78 \%$ were recorded at DWP-5.

Table 2. Contribution of different impact categories to total impact of each scenario at 3 different downstream: $100 \mathrm{~m}, 40,000$, and 80,000 m.

\begin{tabular}{|c|c|c|c|c|c|c|c|c|c|}
\hline & \multicolumn{3}{|c|}{ Scenario-1 } & \multicolumn{3}{|c|}{ Scenario-2 } & \multicolumn{3}{|c|}{ Scenario-3 } \\
\hline & $100 \mathrm{~m}$ & $40,000 \mathrm{~m}$ & $80,000 \mathrm{~m}$ & $100 \mathrm{~m}$ & $40,000 \mathrm{~m}$ & $80,000 \mathrm{~m}$ & $100 \mathrm{~m}$ & $40,000 \mathrm{~m}$ & $80,000 \mathrm{~m}$ \\
\hline $\mathrm{ADE}$ & $1.61 \%$ & $1.74 \%$ & $2.21 \%$ & $0.86 \%$ & $1.29 \%$ & $1.75 \%$ & $0.38 \%$ & $0.61 \%$ & $0.90 \%$ \\
\hline $\mathrm{ADF}$ & $6.87 \%$ & $7.41 \%$ & $9.43 \%$ & $3.74 \%$ & $5.59 \%$ & $7.58 \%$ & $2.29 \%$ & $3.67 \%$ & $5.38 \%$ \\
\hline GW & $8.38 \%$ & $9.05 \%$ & $11.51 \%$ & $4.80 \%$ & $7.16 \%$ & $9.72 \%$ & $2.84 \%$ & $4.57 \%$ & $6.68 \%$ \\
\hline OD & $0.09 \%$ & $0.09 \%$ & $0.12 \%$ & $0.05 \%$ & $0.07 \%$ & $0.10 \%$ & $0.02 \%$ & $0.03 \%$ & $0.05 \%$ \\
\hline HT & $1.76 \%$ & $1.90 \%$ & $2.41 \%$ & $0.95 \%$ & $1.41 \%$ & $1.92 \%$ & $0.54 \%$ & $0.87 \%$ & $1.27 \%$ \\
\hline FAET & $13.74 \%$ & $14.83 \%$ & $18.86 \%$ & $7.29 \%$ & $10.88 \%$ & $14.76 \%$ & $4.26 \%$ & $6.84 \%$ & $10.01 \%$ \\
\hline $\mathrm{PO}$ & $2.34 \%$ & $2.30 \%$ & $3.21 \%$ & $1.20 \%$ & $1.91 \%$ & $0.59 \%$ & $0.78 \%$ & $1.26 \%$ & $1.84 \%$ \\
\hline A & $7.85 \%$ & $8.47 \%$ & $10.78 \%$ & $4.17 \%$ & $6.23 \%$ & $8.45 \%$ & $2.57 \%$ & $4.13 \%$ & $6.04 \%$ \\
\hline $\mathrm{BDO}$ & $57.37 \%$ & $54.01 \%$ & $41.49 \%$ & $76.85 \%$ & $65.48 \%$ & $53.17 \%$ & $86.31 \%$ & $78.02 \%$ & $67.86 \%$ \\
\hline
\end{tabular}

\section{Discussion}

Characterizing the potential bacterial depletion of oxygen is a midpoint impact assessment that explains the quantitative relationship between water pollutants, such as chemical oxygen demand (COD) and its midpoint impact. Coupled with water quality models, the developed 1DCCM and 2DCCM could better represent a more specific midpoint effect by aggregating water pollutants' migration and transformation in the receiving water. Although the choice of aerobic or anaerobic state was insignificant in this study, in LCA practice, using anaerobic bacterial growth as the characterization state would increase the characterization result of the BDO impact category and add weight to the BDO impact category among the trade-offs across various impact categories.

The impact assessment obtained from general characterization models were generalizable, so the characterization results usually account for potential site-generic impact to the total environment. considerable work has been completed to consider regional environmental characteristics in the LCA framework [36-40]. By integrating water quality models into the BDO characterization model in this study, the characterization results were more site-specific in terms of the WWTP cases. More importantly, the 1DCCM and 2DCCM allow for more flexible LCA analysis, exploring one-scenario environmental implications in light of different receiving water features and comparing different scenarios' environmental implications with a wider evaluating scope. Thus, more informative results could be obtained. Obtaining more informative results means that more information is needed. Except for the emission amount of water pollutants needed in the general eutrophication characterization models, longitudinal parameters relevant to the downstream water body were necessary for the calculation of 1DCCM, and both longitudinal and horizontal parameters were indispensable for 2DCCM. To capture the migration and transformation of water pollutants more accurately, a three-dimensional water quality model might be coupled with LCA characterization models in the future. If so, vertical parameters would be required. Collecting these parameters related to the receiving water would, to some extent, increase the complexity of performing the LCA analysis.

With the coupling models, the potential contribution of COD and TN to bacterial depletion of oxygen could be modelled and quantified. Similarly, contribution to the eutrophication potential 
could be addressed by the coupling models. However, the coupling models would not be able to simultaneously address the eutrophication and bacterial depletion of oxygen. To avoid repeated calculations, the amount of water pollutants that were accounted for by the eutrophication potential cannot be used again in the characterization of bacterial depletion of oxygen. Maybe a relevant scientific principle is needed to distribute the water pollutants reasonably in order for coupling models to convincingly quantify both eutrophication and BDO.

In the present work, the potential bacterial growth has been put forward as the characterization state of the evaluated downstream river sections. During the process of migration and transformation, the self-purifying mechanism could also be accounted for by the potential bacterial growth, partly due to the metabolic activity of bacteria whose growth is activated by water pollutants. Thus, bacterial growth could be treated as the force driving the removal of water pollutants before water pollutants reach the evaluated downstream water body, and could be regarded as the potential environmental impact once water pollutants have entered the evaluated downstream waterbody. There is an limitation in the application of 1DCCM or 2DCCM in full LCA analysis: there is no mechanism to handle the situation where the environmental carrying capacity is broken down so that the self-purifying mechanism fails to operate anymore before water pollutants reach the evaluated downstream waterbody. This issue highlights a future research direction for coupling models, where the potential environmental impact characterized by bacterial growth could be linked with the environmental carrying capacity of receiving water.

The self-purifying mechanism was the major basis for the development of 1DCCM and 2DCCM. Another important mechanism that was not considered here was that a greater water volume of the receiving water could help dilute the content of water pollutants, contributing to the reduction of the negative effect of water pollutants. A greater water volume was generally represented by higher water velocity, meaning that with the consideration of the effect of dilution in coupling models, a higher velocity would drive a decrease in $I_{B D O}$, opposite of the tendency shown in Figure 1 . As the coupling models continue to develop, it is important to synthesize the dilution effect and self-purifying effect improve the simulation of water pollutant activity in receiving water in the LCA characterization results.

\section{Conclusions}

In order to map the oxygen depleting potential caused by bacterial growth due to the release of water pollutants (COD and TN) and the fate of water pollutants in receiving water (transportation and transformation), we defined and developed a new impact category, the Bacterial Depletion of Oxygen (BDO) category, and its associated characterization models and factors. Characterization factors were calculated based on the chemical composition of the bacterial biomass. Coupling models (1DCCM and 2DCCM) were formed by integrating the BDO category into WQMs. By incorporating site-specific information into the evaluation process, the coupling models enabled the LCA of wastewater-related issues for actual regional situations. The impacts of parameters on modelling output ( $I_{B D O}$ value) were investigated, and the results showed that the $I_{B D O}$ value was reduced by the increase in the downstream distance and self-purification coefficients but was raised by the increase in water velocity. Future development of the BDO category and coupling models need to create links with the dilution effect of the receiving environment, and include the more completed processes of oxygen depletion and water pollutant behavior.

Author Contributions: S.B. and X.Z. performed the experiments and wrote the paper. X.W. and N.R. contributed to the discussion and analyzed the experiments.

Funding: This research was funded by the National Key R\&D Program (No. 2016YFC0401105), State Key Laboratory of Urban Water Resource and Environment (Harbin Institute of Technology) (No. XQ2018002), and the National Natural Science Foundation of China (Grant No. 31870110).

Conflicts of Interest: The authors declare no conflict of interest. 


\section{References}

1. Alfonsin, C.; Lebrero, R.; Estrada, J.M.; Muñoz, R.; Kraakman, N.B.; Feijoo, G.; Moreira, M.T. Selection of odour removal technologies in wastewater treatment plants: A guideline based on Life Cycle Assessment. J. Environ. Manag. 2015, 149, 77-84. [CrossRef] [PubMed]

2. Harder, R.; Heimersson, S.; Svanstrom, M.; Peters, G.M. Including pathogen risk in life cycle assessment of wastewater management. 1. Estimating the burden of disease associated with pathogens. Environ. Sci. Technol. 2014, 48, 9438-9445. [CrossRef] [PubMed]

3. Heimersson, S.; Harder, R.; Peters, G.M.; Svanstrom, M. Including pathogen risk in life cycle assessment of wastewater management. 2. Quantitative comparison of pathogen risk to other impacts on human health. Environ. Sci. Technol. 2014, 48, 9446-9453. [CrossRef] [PubMed]

4. Pasqualino, J.C.; Meneses, M.; Abella, M.; Castells, F. LCA as a decision support tool for the environmental improvement of the operation of a municipal wastewater treatment plant. Environ. Sci. Technol. 2009, 43, 3300-3307. [CrossRef] [PubMed]

5. Risch, E.; Gutierrez, O.; Roux, P.; Boutin, C.; Corominas, L. Life cycle assessment of urban wastewater systems: Quantifying the relative contribution of sewer systems. Water Res. 2015, 77, 35-48. [CrossRef] [PubMed]

6. Yoshida, H.; Clavreul, J.; Scheutz, C.; Christensen, T.H. Influence of data collection schemes on the Life Cycle Assessment of a municipal wastewater treatment plant. Water Res. 2014, 56, 292-303. [CrossRef] [PubMed]

7. Corominas, L.; Foley, J.; Guest, J.S.; Hospido, A.; Larsen, H.F.; Morera, S.; Shaw, A. Life cycle assessment applied to wastewater treatment: State of the art. Water Res. 2013, 47, 5480-5492. [CrossRef] [PubMed]

8. Li, Y.; Hou, X.; Zhang, W.; Xiong, W.; Wang, L.; Zhang, S.; Wang, P.; Wang, C. Integration of life cycle assessment and statistical analysis to understand the influence of rainfall on WWTPs with combined sewer systems. J. Clean. Prod. 2018, 172, 2521-2530. [CrossRef]

9. Bai, S.; Zhu, X.; Wang, X.; Ren, N. Identify stakeholders' understandings of life cycle assessment results on wastewater related issues. Sci. Total Environ. 2018, 622-623, 869-874. [CrossRef] [PubMed]

10. Bai, S.; Zhao, X.; Wang, D.; Zhang, X.; Ren, N. Engaging multiple weighting approaches and Conjoint Analysis to extend results acceptance of life cycle assessment in biological wastewater treatment technologies. Bioresour. Technol. 2018, 265, 349-356. [CrossRef] [PubMed]

11. Basset-Mens, C.; Anibar, L.; Durand, P.; van der Werf, H.M.G. Spatialised fate factors for nitrate in catchments: Modelling approach and implication for LCA results. Sci. Total Environ. 2006, 367, 367-382. [CrossRef] [PubMed]

12. Gallego, A.; Rodriguez, L.; Hospido, A.; Moreira, M.T.; Feijoo, G. Development of regional characterization factors for aquatic eutrophication. Int. J. Life Cycle Assess. 2010, 15, 32-43. [CrossRef]

13. Azevedo, L.B.; Henderson, A.D.; van Zelm, R.; Jolliet, O.; Huijbregts, M.A.J. Assessing the importance of spatial variability versus model choices in life cycle impact assessment: The case of freshwater eutrophication in europe. Environ. Sci. Technol. 2013, 47, 13565-13570. [CrossRef] [PubMed]

14. Helmes, R.J.K.; Huijbregts, M.A.J.; Henderson, A.D.; Jolliet, O. Spatially explicit fate factors of phosphorous emissions to freshwater at the global scale. Int. J. Life Cycle Assess. 2012, 17, 646-654. [CrossRef]

15. Struijs, J.; Beusen, A.; de Zwart, D.; Huijbregts, M. Characterization factors for inland water eutrophication at the damage level in life cycle impact assessment. Int. J. Life Cycle Assess. 2011, 16, 59-64. [CrossRef]

16. Morelli, B.; Hawkins, T.R.; Niblick, B.; Henderson, A.D.; Golden, H.E.; Compton, J.E.; Cooter, E.J.; Bare, J.C. Critical review of eutrophication models for life cycle assessment. Environ. Sci. Technol. 2018, 52, 9562-9578. [CrossRef] [PubMed]

17. Gonzalez, S.O.; Almeida, C.A.; Calderon, M.; Mallea, M.A.; Gonzalez, P. Assessment of the water self-purification capacity on a river affected by organic pollution: Application of chemometrics in spatial and temporal variations. Environ. Sci. Pollut. Res. Int. 2014, 21, 10583-10593. [CrossRef] [PubMed]

18. Meng, W.; Su, Y.; Zheng, B. Analysis of current situation of water pollution and its control strategy for Chinese river basins. J. China Inst. Water. 2004, 4. [CrossRef]

19. MEP. Report on the State of the Environment in China; Ministry of Environmental Protection: Beijing, China, 2014.

20. MEP. Discharge Standard of Pollutants for Municipal Wastewater Treatment Plant (GB18918-2002); China Environment Press: Beijing, China, 2002. 
21. MEP. Surface Water Quantity Standards (GB8938-2002); China Environment Press: Beijing, China, 2002.

22. Pizzol, M.; Weidema, B.; Brandão, M.; Osset, P. Monetary valuation in life cycle assessment: A review. J. Clean. Prod. 2015, 86, 170-179. [CrossRef]

23. Renou, S.; Thomas, J.S.; Aoustin, E.; Pons, M.N. Influence of impact assessment methods in wastewater treatment LCA. J. Clean. Prod. 2008, 16, 1098-1105. [CrossRef]

24. Zang, Y.W.; Li, Y.; Wang, C.; Zhang, W.L.; Xiong, W. Towards more accurate life cycle assessment of biological wastewater treatment plants: A review. J. Clean. Prod. 2015, 107, 676-692. [CrossRef]

25. Zhao, X.; Yang, J.; Zhang, X.; Wang, L.; Ma, F. Evaluation of bioaugmentation using multiple life cycle assessment approaches: A case study of constructed wetland. Bioresour. Technol. 2017, 244, 407-415. [CrossRef] [PubMed]

26. Wang, Q.G.; Li, S.B.; Jia, P.; Qi, C.J.; Ding, F. A review of surface water quality models. Sci. World J. 2013, 2013. [CrossRef] [PubMed]

27. Guinée, J.B. Handbook on life cycle assessment operational guide to the ISO standards. Int. J. Life Cycle Assess. 2001, 7, 311-313. [CrossRef]

28. Scientific Applications International Corporation (SAIC); Curran, M.A. Life-Cycle Assessment: Principles and Practice; National Risk Management Research Laboratory, Office of Research and Development, US Environmental Protection Agency: Cincinnati, OH, USA, 2006.

29. Rittmann, B.E.; McCarty, P.L. Environmental Biotechnology: Principles and Applications; Tata McGraw-Hill Education: New York, NY, USA, 2012.

30. Wu, J.S.; Ahlert, R.C. Applications of a Steady-State, One-Dimensional Water-Quality Model. Water Resour. Bull. 1979, 15, 660-670. [CrossRef]

31. Lap, B.Q.; Mori, K.; Inoue, E. A one-dimensional model for water quality simulation in medium- and small-sized rivers. Paddy Water Environ. 2007, 5, 5-13. [CrossRef]

32. Sudjono, P.; Koga, K.; Araki, H.; Booij, N. Development and application of one-dimensional water quality model for channel networks and tidal rivers. Hydraul. Eng. Softw. VI 1996, 18, 309-319.

33. Buchak, E.M.; Edinger, J.E. User Guide for LARM2: A Longitudinal-Vertical, Time-Varying Hydrodynamic Reservoir Model; Edinger (Je) Associates Inc.: Wayne, PA, USA, 1982.

34. Martin, J.L. Application of two-dimensional water quality model. J. Environ. Eng. 1988, 114, $317-336$. [CrossRef]

35. Covelli, P.; Marsili-Libelli, S.; Pacini, G. SWAMP: A two-dimensional hydrodynamic and quality modeling platform for shallow waters. Numer. Methords Part Differ Equ. 2002, 18, 663-687. [CrossRef]

36. Bellekom, S.; Potting, J.; Benders, R. Feasibility of applying site-dependent impact assessment of acidification in LCA. Int. J. Life Cycle Assess. 2002, 11, 417-424. [CrossRef]

37. Zimmermann, T. Parameterized tool for site specific LCAs of wind energy converters. Int. J. Life Cycle Assess. 2013, 18, 49-60. [CrossRef]

38. Sleeswijk, A.W. Regional LCA in a global perspective. A basis for spatially differentiated environmental life cycle assessment. Int. J. Life Cycle Assess. 2011, 16, 106-112. [CrossRef]

39. Boulay, A.M.; Bulle, C.; Bayart, J.B.; Deschenes, L.; Margni, M. Regional characterization of freshwater use in LCA: Modeling direct impacts on human health. Environ. Sci. Technol. 2011, 45, 8948-8957. [CrossRef] [PubMed]

40. Kim, S.; Dale, B.E. Regional variations in greenhouse gas emissions of biobased products in the United States-corn-based ethanol and soybean oil. Int. J. Life Cycle Assess. 2009, 14, 540-546. [CrossRef]

(C) 2018 by the authors. Licensee MDPI, Basel, Switzerland. This article is an open access article distributed under the terms and conditions of the Creative Commons Attribution (CC BY) license (http://creativecommons.org/licenses/by/4.0/). 